\title{
Land Provision for Decent and Affordable Housing for Low-Income Community in Salatiga City
}

\author{
S. Sunarti $\mathrm{i}^{\mathrm{a}^{*}}$, N. Yuliastuti ${ }^{\mathrm{a}}$ (iD , I. Indriastjario ${ }^{\mathrm{b}}$ \\ a Department of Urban and Regional Planning, Faculty of Engineering, Diponegoro University, Indonesia \\ ${ }^{b}$ Department of Architecture, Faculty of Engineering, Diponegoro University, Indonesia
}

\section{Article Info:}

Received: 10 August 2018

in revised form: 10 October 2018

Accepted: 10 December 2018

Available Online: 30 Dec 2019

\section{Keywords:}

Affordable Housing, Land for

housing, Low-Income Communities

*Corresponding Author:

S. Sunarti

Department of Urban and Regional

Planning, Diponegoro University,

Semarang, Indonesia

Email: sunarti@pwk.undip.ac.id

\begin{abstract}
The need for land for urban housing construction was increasingly difficult and more pricey, so low-income communities for owning a house were not easy. Limited land in an urban area, especially in small cities such as Salatiga, is not all used in housing construction. This condition needed an intervention from the local government to facilitate their needs for housing could be fulfilled. Based on the problems, this research's goals studied a providing of land for decent and affordable housing for low-income communities in Salatiga. The method used was a mixed method with a sequential explanation strategy by overlaying secondary data on the land potential map from various sources that can be used for decent housing with primary data, such as interviews and document reviews with the local government reduce of housing cost. The study results figure out that housing used land owned by the village government can be affordable for low-income communities with price less expensive below the standard set by the government.
\end{abstract}

Copyright (C) 2019 GJGP-UNDIP

How to cite (APA 6th Style):

Sunarti, S., Yuliastuti, N., \& Indriastjario, I. (2020). Land Provision for Decent and Affordable Housing for Low-Income Community in Salatiga City. Geoplanning: Journal of Geomatics and Planning, 6(2), 113-121. doi: 10.14710/geoplanning.6.2.113-121

\section{INTRODUCTION}

The Declaration of the Universal Declaration of Human Rights (1948) states that everyone has the right to a standard of living in inadequate housing conditions. In accordance with the declaration, housing is one of the basic necessities of every human being. Everyone needs a home, but not everyone can fulfill housing needs. The increasing rate of population growth and the phenomenon of urbanization in big cities that affect the surrounding small towns has resulted in an increase in the need for urban space, especially the fulfillment of housing and settlement needs.

When the scale of urbanization has increased, the provision of decent housing for low - income people in cities survive as one of the problems is quite difficult to deal with in developing countries (Teke, 2011). Other researchers stated that urban areas in developing countries are experiencing difficulties in providing adequate and affordable land to meet the housing needs of urban communities. This impacts low-income communities who have difficulties accessing decent and affordable housing (Gbadegesin, Heijden, \& Boelhouwer, 2016). Generally, housing affordability is a relationship between household income and the housing price level (Li et al., 2017). Affordable housing for low-income communities is housing that has a price of less than $30 \%$ of household income. The United Nations defines when families spend more than $30 \%$ of housing considered as expenses cannot even meet other needs such as food, clothing, education, transportation, and medical (Alaghbari et al., 2011).

The study of housing has long been an important target of public policy in society, especially in urban areas (Cai \& Lu, 2015). The Turkish Government carries out one implementation of the public government in the provision of housing and settlements for low- and middle-income people in the provision of land for 
settlement areas and payment schemes for low- and middle-income communities. Thus, meeting the needs of providing housing for low-income people in need of government intervention.

Salatiga is one of the small cities in Central Java Province, which is developing quite rapidly and heterogeneous areas around the big cities of Central Java (Prawatya, 2013). Along with the natural population growth and rapid urbanization, movement affects the availability of land. The administrative availability of land is a fixed value, but the demand for housing land is increasing. This will have an impact on low-income communities, not having the ability to own a house. Ironically, the tendency of the high number of backlogs that occur due to the gap between the demand and supply of houses to low-income communities is very worried. The existence of these conditions, Salatiga's Government has managed to help low-income communities, especially for Government Civil Servants (PNS) in the provision of houses by releasing land assets belonging to the local government to the public, so as to reduce the price determined in accordance with the policy of the central government. Land release owned by the local government is based on Government Regulation No. 27 of 2014 on the Management of State/Regional Property.

In previous research related to the provision of housing and settlements for low and middle-income communities (Palancioglu \& Cete, 2014). The research is a housing development scheme for low and middle-income people who are adequate in terms of quantity with social and physical conditions in a short time and affordable.

Based on this gap, this study focuses on public government efforts in providing affordable housing for low-income communities where using assets from local governments. This study is related to the efforts of Salatiga's government in managing local government assets for the provision of decent housing for lowincome communities.

\section{DATA AND METHODS}

The method used in this study is a mixed-method, which is a combination of qualitative and quantitative approaches (Creswell, 2010; Bryman, 2006). The research method was a mixed-method with a sequential explanatory strategy. The strategy of this method applied data collection and quantitative analysis followed with the collection data and qualitative analysis. Data collected by primary and secondary. They are primary data collected by interviewing informants and secondary data collected by literature, planning studies, policies, articles, and reference books. Informants are the governments involved in hand over the land assets from the government to the public, such as Departments of Housing and Settlement, Department of Public Works and Spatial Planning, and Departments of Local Financial Revenue.

This section will describe the research design and analytical model for the provision of land for affordable housing for low-income communities in Salatiga and supported by primary and secondary data as data sources. This study combines qualitative and quantitative approaches in different phases of the research process (Terrell, 2012).

Analysis of the land provision for housing low-income communities seen of the value of housing needs in Salatiga. Housing needs are based on the value of the backlog in Salatiga and low-income demographic data. This study focuses on Government Civil Servant, especially classes of II and III, as objects of lowincome communities in housing land provision. The registered names filed to be able to own a house are 1920 persons. The number of housing needs in Salatiga as the basic data to analyze the potential of the region as a settlement.

Potential for the provision of residential land for MBR based on an overlay of land mapping using a settlement area based on the Urban Land Use Plan document (RTRW) of Salatiga relate to the settlement area Salatiga. The overlay of both data figures out the locations of potential areas as new settlements. Location determination is not only based on potentially residential locations. Local Government intervention as an effort of the provision of affordable housing using local assets, which are located in the plan of a settlement area. The availability of land assets and new settlement potential areas were utilized to provide land for affordable housing for low-income communities. 


\section{RESULT AND DISCUSSION}

\subsection{General Description of Salatiga City}

Salatiga is one of the small cities in Central Java, which is located in the middle of the Semarang Regency. Administratively, Salatiga consists of 4 sub-districts and 23 urban villages with an area of 5.678 hectares (Central Bureau of Statistics in Salatiga, 2017). They were Argomulyo Subdistrict has 6 urban villages, Tingkir Sub-district has 7 urban villages, Sidomukti Sub-district has 4 urban villages, and Sidorejo Sub-district has 6 urban villages. In 2016 the land area used for housing and settlement was 1.618,85 hectares, which is spread in every Sub-District. The condition of the existing location of housing and settlement in Salatiga could see in the Figure 1.

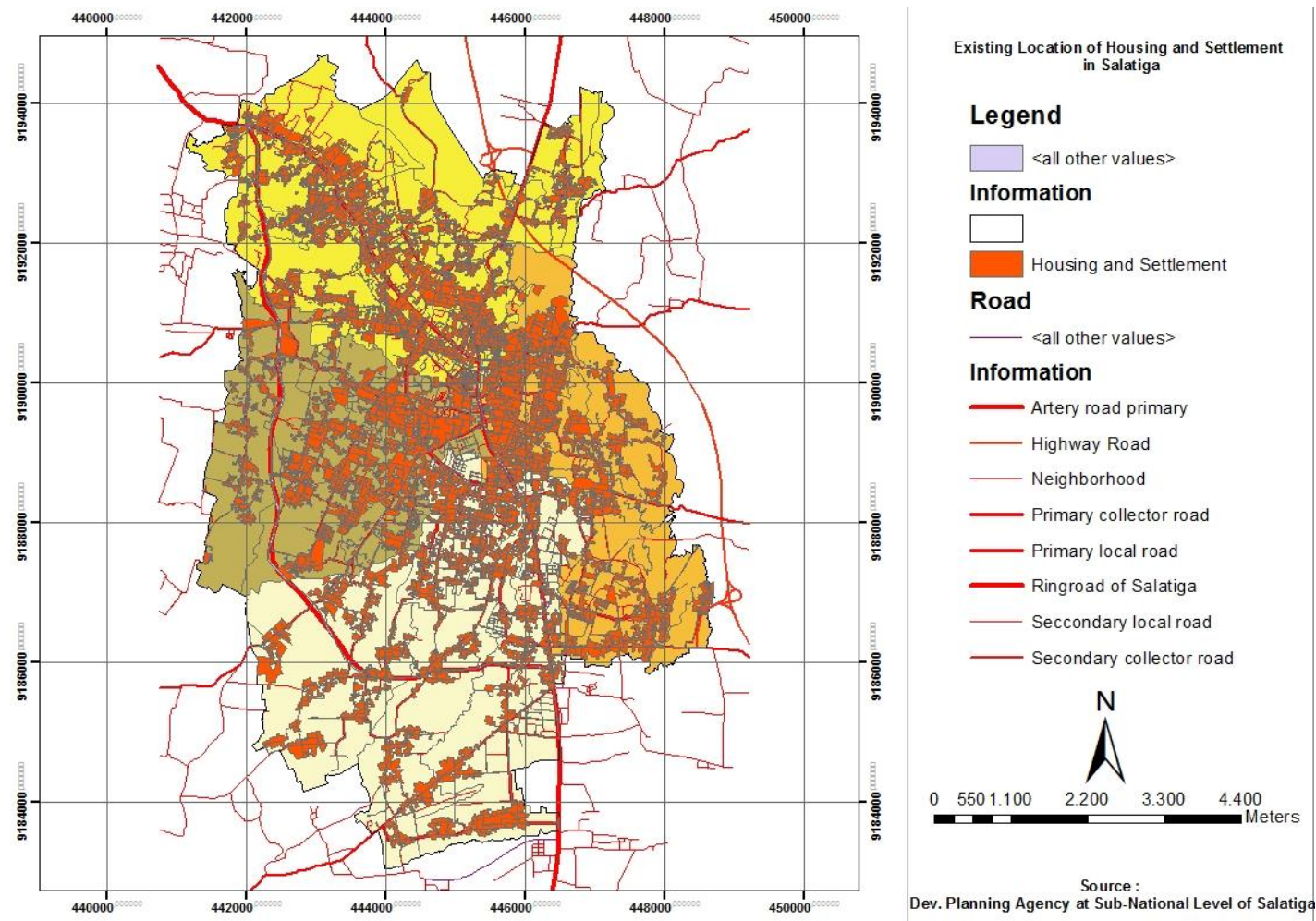

Figure 1. Existing Location of Housing and Settlement in Salatiga of 2016

In 2015 , houses in Salatiga as many as 41,889 housing units. However, this number has not accommodated the housing demand in Salatiga. The number of backlog in the Salatiga reached 4.068 housing units. Reducing the number of backlogs, the Salatiga government is trying to build housing for lowincome communities with affordable prices. Actions are undertaken by local governments, especially coordinate with the Governing Board of KORPRI (Corps of Government Civil Servants of the Republic of Indonesia) in the form of list their names in accordance with the requirement as many as 1920 employees class II and III who do not have a house yet. A government civil servants (PNS) class II was civil servants who have maximum educated was the senior high school with maximum salary as much as Regional Minimum Wage $(U M R)$ and class III was civil servants with minimum educated was undergraduate with a minimum salary above a Regional Minimum Wage (UMR). Land plans for housing and settlements in Salatiga in the next 20 years until 2036 years as much as 639.22 Hectares. The land acquisition location plan was used to fulfill the demand for houses in Salatiga City, both for reducing a backlog of house ownership or for all populations' growth.

\subsection{Analysis of Housing Land Potential}

This analysis explains the potential of land in Salatiga from the existing location of settlements and settlement plans. This study helps in viewing the locations of land that can be used as a new settlement in accordance with the Urban Land Use Plan Document of Salatiga. The study of potential as settlement land 
is supported by demographic data based livelihoods in productive age, a percentage of the backlog in Salatiga, with existing location and land use plan as settlement.

Planning for housing area refers to National Law Number 1 of 2011 concerning housing and settlement area planning. There are several criteria in the planning of housing area, they are :

1. The use of space appropriate land capacity and providing a healthy environment, safe, and can provide a living environment in accordance with community development.

2. Available for road infrastructure and public transportation services are available/served by public transportation.

3. Management of area supported by public facilities and social facilities.

Determination of housing area based on location characteristics and land suitability adjusted with characteristic and carrying capacity. Landed use for the new housing area is $40 \%$ until $60 \%$ of the existing land (Hilmasyah \& Rudiarto, 2015). Besides that, a new housing area equipped with public utilities and a maximum of housing building density did not structure as much above 50 houses per hectare (Hilmasyah \& Rudiarto, 2015). In addition, it refers to the Ministry of Regulation Number 41/PRT/M/2007 mention related criteria to develop housing area, they are :

1. The land's topography is the flat slope and moderate slope (slope is $0 \%$ until $25 \%$ ).

2. Available of the water source, both groundwater or water, managed by an organizer.

3. The location was not in a disaster-prone area.

4. The drainage condition is good to a medium.

5. Location was not in river barriers, beaches, reservoirs, lakes, wellspring, irrigation, railways, and safe flight areas.

6. The location was not in an area needing protection and was not in fishery farming, agriculture, or buffer area.

According to the Urban Land Use Plan Document and RP3KP of Salatiga mention, some land locations were potential as new settlements (City Government of Salatiga, 2016). The area of potential land as new housing and settlements in each Sub-District (Table 1).

Table 1. The land area as potential new Housing and Settlements of $2016-2036$ in Salatiga based on RP3KP Document

\begin{tabular}{lrr} 
& Sub-District & Land Area (Hectares) \\
\hline Argomulyo & 121,76 \\
\hline Tingkir & 116,08 \\
Sidomukti & 170,80 \\
Sidorejo & 230,58 \\
Total & 639,22 \\
\hline
\end{tabular}

The land area can be used to a new location for housing and settlement all society and especially for providing a settlement of low-income communities. Argomulyo Sub-District and Sidomukti Sub-District have a wider area to used as a settlement. Thus, both Sub-District were more potentially used for a new settlement because they have a wider area than other Sub-District.

The potential of settlement land also saw a number of the backlog in Salatiga. Salatiga had experienced a deficit in providing the housing. The difference between the demand for house dan existing housing (backlog) was 4.089 house units in 2015 (Figure 2). The highest number of a gap in Sidorejo SubDistrict with number reached 2.915 house units. Then, Sidomukti Sub-District, with a number of gaps was 799 house units, Tingkir Sub-District gap number reached was 317, and the lowest gap number reached 37 house units in Argomulyo. The table above was the planned land potential for the provision of housing and settlements for all community groups, including for low-income and poor communities. 


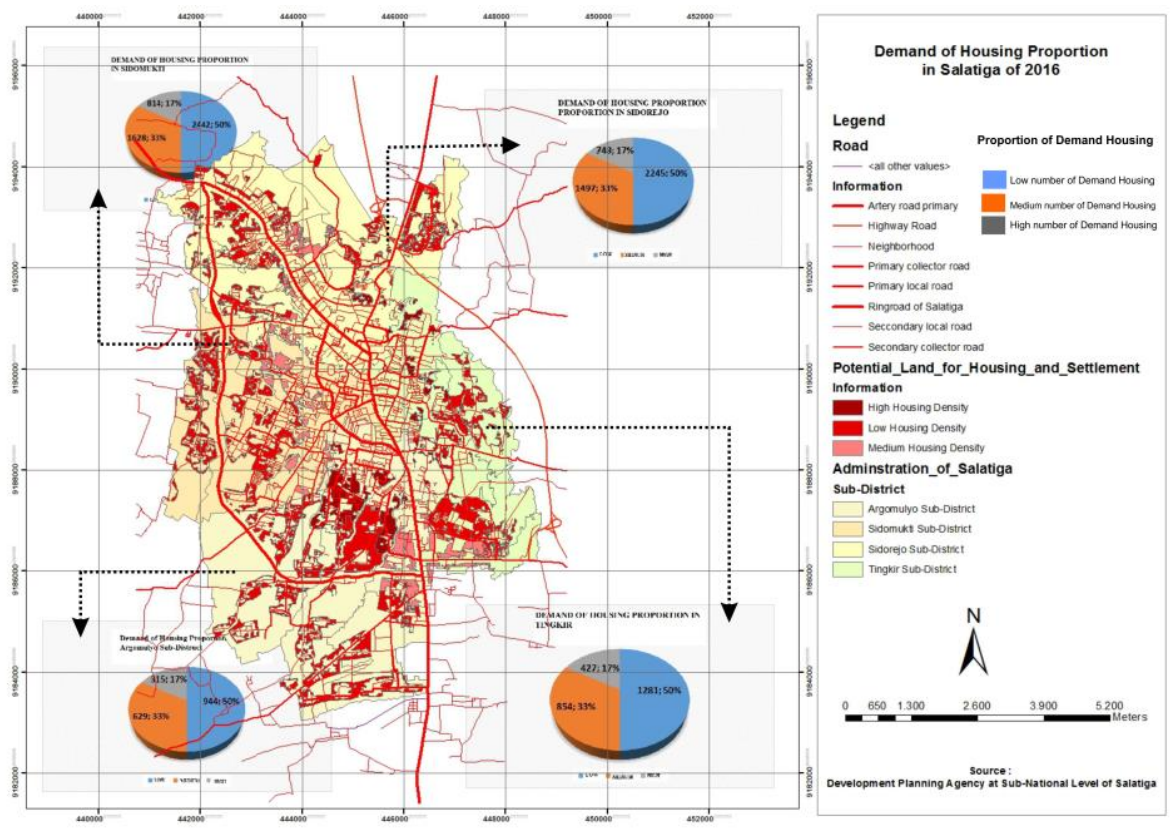

Figure 2. Proportion demand for housing in Salatiga of 2016

In the picture above that the gap between the demands of the housing and the availability of land in each sub-district for the developing of houses for all community groups. The provision of housing land for low-income communities was included in the plan. The cost of urban land in every sub-districts is more expensive, making it difficult for low-income people to reach. Thus, it requires government intervention in the provision of adequate and affordable housing for low-income communities. The provision of service housing for low-income communities was not effective by the formal market mechanism because production and housing construction payments were more expensive. In contrast, informal mechanisms tended to produce a solution that was less expensive than the standard price (Rojas \& Greene, 1995). Thus, to fulfill the needs of formal housing and settlement in Salatiga was not easy because the limited land caused housing costs more expensive. For low-income communities, it was hard enough to have formal market mechanisms. With limited land, the potential land that can be constructed for housing must be effective and can be used for public welfare for all civil society (Figure 3 ).

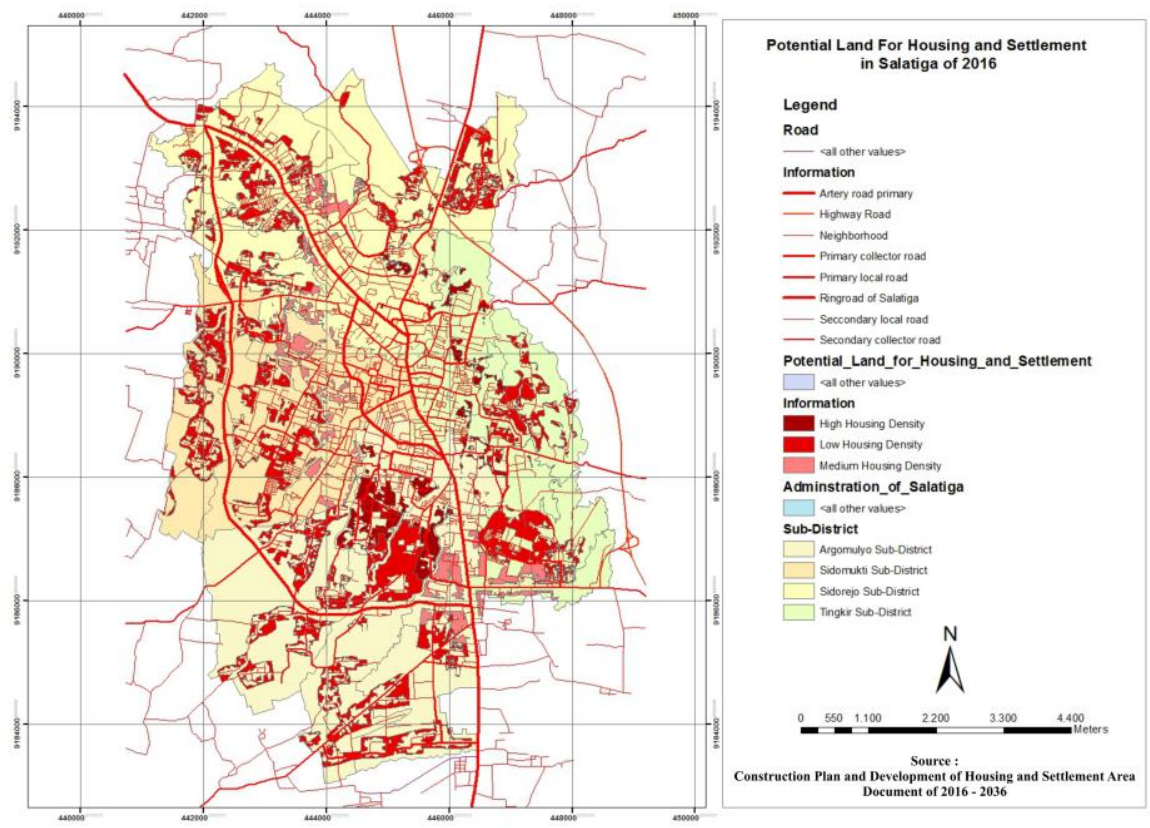

Figure 3. Location of Housing potential in Salatiga of 2016 - 2036 
Provision of affordable housing for low-income communities saw from several aspects to supported affordability for the communities. Affordable housing design by a case study the government Queensland give the initiative in promoting the design and construction of the settlement. Affordable for housing summarized in several aspects, they are :

1. The social settlement was designed safe and comfortable for residents.

2. Environment sustainability with the availability of waste management, water, and energy.

3. Economic, affordable and efficient cost from time to time.

Potential land for housing and settlement in Salatiga has in accordance with the criteria, but it could not be affordable by low-income communities with their limited economics. This condition can cause the government policy of Salatiga to helped low-income communities by handed over half of the land assets owned by the government (ex-a land by the village administration) to low-income communities for reducing cost standards.

\subsection{Analysis of Land Local Government Assets}

The government of Salatiga's effort in the provision of land for housing saw the potential of the new area as settlement based on the Urban Land Use Plan of Salatiga. The availability of land as a settlement has a lot of potentials, which is distributed on some Sub-District. But, not all communities could access dan reach of that land. This is the financial constraint of low-income communities to have land for good and decent fulfillment.

The government of Salatiga has several land assets scattered in every Sub-District of Salatiga. Land assets were (Tanah Bengkok), which is private land owned by village administration and handed over to the local government of Salatiga. Those assets landed use, such as agriculture, plantation, moor, field, public facilities, and social facilities. The area of land from landed use of government assets in every Sub-District could be seen on the Table 2-5.

Table 2. Landed Use of Ex-a land owned by the village government (ETB) in Argomulyo Sub-District in 2017

\begin{tabular}{lrr}
\hline Landed Use & Area $\left(\mathrm{m}^{2}\right)$ & Percentage \\
\hline Plantation & 402.629 & $45 \%$ \\
\hline Settlement & 1904 & $0 \%$ \\
\hline Office & 7407 & $1 \%$ \\
\hline Social Facilities & 20.838 & $2 \%$ \\
\hline Building water storage facilities & 3.765 & $0 \%$ \\
\hline Field & 30.360 & $3 \%$ \\
\hline Agriculture & 327.358 & $37 \%$ \\
\hline Rice Field & 52.783 & $6 \%$ \\
\hline Moor & 39.420 & $4 \%$ \\
\hline \multicolumn{1}{c}{$\quad$ Total } & 886.464 & $100 \%$ \\
\hline
\end{tabular}

Table 4. Landed Use of Ex-a land owned by the village government $(E T B)$ in Sidorejo Sub-District in 2017

\begin{tabular}{lrr} 
Landed Use & Area $\left(\mathrm{m}^{2}\right)$ & Percentage \\
\hline Agriculture ( Rice Field) & 42.372 & $5 \%$ \\
\hline Agriculture (Moor) & 45.305 & $5 \%$ \\
Agriculture & 724.990 & $86 \%$ \\
Office Building & 7.039 & $1 \%$ \\
\hline
\end{tabular}

Table 3. Landed Use of Ex-a land owned by the village government (ETB) in Sidomukti SubDistrict in 2017

\begin{tabular}{lrr} 
Landed Use & Area $\left(\mathrm{m}^{2}\right)$ & Percentage \\
\hline Moor & 2.674 & $1 \%$ \\
\hline Rice Field & 2.521 & $1 \%$ \\
\hline Agriculture & 338.821 & $89 \%$ \\
\hline Park & 3.570 & $1 \%$ \\
\hline Field & 5.739 & $1 \%$ \\
\hline Social and Public Facilities & 29.687 & $8 \%$ \\
Settlement & 5.021 & $1 \%$ \\
\hline Office & 14.155 & $4 \%$ \\
& 382.838 & $100 \%$ \\
\hline \multicolumn{1}{c}{ Total } & & \\
\hline
\end{tabular}

Table 5. Landed Use Ex-a land owned by the village government (ETB) Tingkir Sub-District in 2017

\begin{tabular}{lrr}
\multicolumn{1}{c}{ Landed Use } & \multicolumn{1}{c}{ Area $\left(\mathrm{m}^{2}\right)$} & Percentage \\
\hline Agriculture & 175.853 & $27 \%$ \\
Rice Field & 415.604 & $64 \%$ \\
Moor & 18.548 & $3 \%$ \\
Settlement & 7.205 & $1 \%$ \\
\hline
\end{tabular}




\begin{tabular}{|c|c|c|c|c|c|}
\hline Field & 11.480 & $1 \%$ & Office & 8.238 & $1 \%$ \\
\hline Social Facilities & 9.865 & $1 \%$ & Social Facilities & 4.152 & $1 \%$ \\
\hline Bathing Place & 255 & $0 \%$ & Field & 20.148 & $3 \%$ \\
\hline Total & 841.306 & $100 \%$ & Total & 649.748 & $100 \%$ \\
\hline
\end{tabular}

Based on Ex land owned by the village government of Land use in 2017, the majority percentage of landed use of ETB as local government assets used for plantations and agriculture (rice field and moor). The largest area of land in Argomulyo Sub-District. That land was land owned by the village administration and handed over to the local government of Salatiga. The availability land of local government and then fulfillment demand of housing for low-income communities by made use of a land asset, which is located in accordance with Urban Planning of Salatiga. The above data represented land assets in 2017, but a land asset for providing housing for government civil servants (PNS) took asset land in 2007. That land asset as dry-soil agriculture and was converted as a settlement area. In 2007 for providing a demand for housing for low-income communities related to housing because of the inability of low-income communities to have a house, the local government has removed half of their assets (land) for society as their housing settlement. The location of local government land assets has been removed for housing in the land that was used before as dry-soil agriculture. The chosen location was Kecandran Urban Village, Sidomukti Sub-District, and Randuacir Urban Village, Argomulyo Sub-District in Salatiga. The selection of both location because it was the largest land asset than other land assets of local government that could use to housing.

Land acquisition of local government for providing housing of low-income communities, especially for government civil servants distributed in some locations. Provision of facilities and infrastructure for the housing of government civil servants (PNS) were in some location, they are :

1. Ex-Land owned by the village government (Eks Tanah Bengkok) in Kecandran Urban-Village with area of $59.207 \mathrm{~m}^{2}$.

2. Right over land Number 27 on behalf of Salatiga government with an area of $48.115 \mathrm{~m}^{2}$.

But the land acquisition of the Salatiga government with compensation to prospective landowners or PNS divide in two ways, they are :

1. Half of the land Bengkok in Kecandran Urban Village with an area of $31.420 \mathrm{~m}^{2}$ for built 400 house units in Prajamukti.

2. Half of Right over land number 27 in Salatiga with an area of $31.420 \mathrm{~m}^{2}$ which is builed 345 house units in Prajamulya.

Disposal of right assets from government to public accordance Regulation in Lieu of Law number 27 of 2014 about Management Regional/National Owned Goods stated that owner of regional or national owned goods could propose the utilization and transfers regional owned goods form of land or building that was not required the approval Municipal Regional Houses of People's Representatives (DPRD) and regional owned goods besides from land and building. And the last could be owned for the public. Still, to avoid any problems in the future, The Indonesian civil servant's corps submitted an application to the Municipal Regional Houses of People's Representatives (DPRD) of Salatiga to approve the disposal of land assets owned by the government to the public. In relation to the local government's land assets, DPRD approved the transfers and removed land from the inventory list for housing development to government civil servants in Salatiga. Disposal of assets refers to some regulation provision which is supported for transfers regional owned assets to society, such as:

1. Government Regulation of Indonesia number 38 of 2008 about Management of National/Regional owned goods.

2. Government Regional number 50 of 2006 about Managements of goods.

3. Minister of Home Affairs Regulation Number 17 of 2007 about Technical Guidelines for Regional Property Management.

4. Decision of municipal Regional Houses of People's Representatives (DPRD) of Salatiga about Committee for the removed of regional owned goods for provision housing KORPRI in 2012. 
Based on regulation before, government land assets have to release can be utilized for the settlement of low-income communities. Then the price of government civil servants, especially class II and III, can be cheaper. They only replaced with the land at a price in accordance with land and building tax imposition base (NJOP). Land used for housing comes from these government assets, it can depress home prices that are offered to the public at a price below the standards set by the government.

\subsection{Analysis of Affordable Housing for Low-Income Communities}

Generally of affordable housing could see from economic aspects in the ability to buy a housing unit. Based on spending money on housing, this condition was not more than $30 \%$ of household income. This agrees with the research of providing affordable housing for low-income communities in Yamen, which is an economic aspect of affordable housing.

The provision of affordable housing for low-income communities from the land relinquishment of government assets could reduce the number of the backlog in Salatiga. Reduction of the backlog in Salatiga was providing 745 of house units to 745 families from 1920 government civil servants who had not had a house. Government interventions in providing land for low-income communities in accordance with formal market mechanisms could help reduce the price of housing, which has to be paid by the community. Affordability in the provision of housing and settlement for low-income communities provided the land and the effort of pressing cost.

The affordability of housing payments was seen at the price of one house unit of IDR $85,000,000$. This price was below the standard of price housing and could access a mortgage (KPR FLPP) by the Ministry of Public Works and Human Settlement (PUPR). Based on the standard was given by PUPR, the housing price of the mortgage was IDR 130.0000.0000. The local government of Salatiga has pressed as many as $34 \%$ from standard pricing. In addition, pressed of cost a housing unit of mortgage, pressing of cost also got price support by the Ministry of Public Works and Human Settlement (PUPR) as much as IDR 4.000 .000 as an advance payment for the land. And then pressing of the cost was also gotten help from Bank BTN (Bank Tabungan Negara) to make commercial loans. So, the owner's candidate could make a payment of credit in one month was Idr 835.000 within a period of 15 years until 20 years. Provision of housing dan settlement for low-income communities, especially for government civil servants classes of II and III, has been done since 2007. Since 2007 has done list names of owner's candidate with several criteria, such as :

1. Government civil servants (PNS) in Salatiga.

2. Priority for PNS class II and III.

3. Priority for PNS who has worked in Salatiga more than 5 years.

4. Couples Husband and Wife of PNS can only have 1 house unit.

5. Prioritized government civil servants who had not have a house.

6. Government Civil servants who have a job tenure before December 2012.

Requirement of above, government civil servants who register as much as 1.920 employees, but a limited land asset of ex-land owned by village government and has owned by the local government only has built 735 house units. The next plan of Salatiga's government will build housing for low-income communities in the Sub-District, who have some land assets that can be used for housing and settlement. But over time, in the process of housing development, the owner's candidate has changes job titles. So the number of job status changes has influenced inappropriately in the purpose and goals of providing housing for low-income communities. So, some owner's candidate was not appropriate with criteria.

\section{CONCLUSION}

Salatiga is one of the small cities in Central Java with a lot of development as an attraction to the increase in activities and demand for housing, especially for low-income communities. However, not all low-income communities have the opportunity to obtain affordable land for housing demand. Provision of government land assets by the transfers to the public as an effort providing affordable housing. From the government, assets have some asset location that can be used as providing low-income communities 
housing. Intervention from the local government for fulfillment providing affordable housing not only focuses on the land provision. Payment scheme as an effort to pressing of cost in the payment process for low-income communities. The standard of a unit house with a mortgage (KPR) was IDR 130.000.000, but the local government has pressed of cost until 34\% or IDR 45.000.000. Low-income communities can claim affordable ownership of a unit house with a price under the standard. This Salatiga city government policy can be a lesson learned for other local governments to help low-income communities in affordable homeownership. The government policy of Salatiga in providing housing and settlement in the future should do not reduce land assets owned by local government. A land status did not remove the public-right but providing a housing and settlement approach was rent.

\section{ACKNOWLEDGMENTS}

Researchers would like to thank the donor of funds, namely the University of Diponegoro for Research on the Development and Application of Funds in addition to the State Budget of Diponegoro University in the 2018 fiscal year with contract number 474-36/UN7.P4.3/PP/2018. So with these funds, the researcher can complete the research.

\section{REFERENCES}

Alaghbari, W., Salim, A., Dola, K., \& Ali, A. A. A. (2011). Developing affordable housing design for low income in Sana'a, Yemen. International Journal of Housing Markets and Analysis, 4(1), 84-98. [Crossref]

Bryman, A. (2006). Integrating quantitative and qualitative research: How is it done? Qualitative Research, 6(1), 97-113. [Crossref]

Cai, W., \& Lu, X. (2015). Housing affordability: Beyond the income and price terms, using China as a case study. Habitat International, 47, 169-175. [Crossref]

Central Bureau of Statistics in Salatiga. (2017). Salatiga in Fiures 2017.

Creswell, J. W. (2010). Research Design: Pendekatan Kualitatif, Kuantitatif dan Mixed. Yogyakarta: Pustaka Pelajar Yogyakarta.

Gbadegesin, J. T., Heijden, H. Van Der, \& Boelhouwer, P. (2016). Land Accessibility Factors in Urban Housing Provision in Nigeria Cities : Case of Lagos ., (2015).

Hilmasyah, H., \& Rudiarto, I. (2015). Kajian Perkembangan dan Kesesuaian Lahan Permukiman Eksisting di Kecamatan Indramayu, 4(1), 54-65.

Li, L. H., Wu, F., Dai, M., Gao, Y., \& Pan, J. (2017). Housing affordability of university graduates in Guangzhou. Habitat International, 67, 137-147. [Crossref]

Palancioglu, H. M., \& Cete, M. (2014). The Turkish way of housing supply and finance for low- and middleincome people. Land Use Policy, 39, 127-134. [Crossref]

City Government of Salatiga. (2016). Salatiga Spatial Planning. RP3KP Program: Salatiga.

Prawatya, N. A. (2013). Perkembangan Spasial Kota-Kota Kecil Di Jawa Tengah. Jurnal Wilayah Dan Lingkungan, 1(April), 17-32.

Rojas, E., \& Greene, M. (1995). Reaching the poor: Lessons from the Chilean housing experience. Environment \& Urbanization, 7(2), 31-50. [Crossref]

Teke, N. (2011). Challenges of Urban Housing Provision in Lagos and Johannesburg. Net publication.

Terrell, S. R. (2012). Mixed-methods research methodologies. The Qualitative Report, 17(171), 254-280. [Crossref] 